\title{
Science of smell wins medicine Nobel
}

\section{Alison Abbott}

How would you react if you got that call from Stockholm? Linda Buck, a neuroscientist from Seattle, fumbled her phone in the dark and accidentally hung up. It was 2.30 in the morning, mind you. Co-winner Richard Axel, her former lab chief at Columbia University in New York, managed to take his call without mishap.

The pair won the 2004 Nobel Prize in Physiology or Medicine this week for their seminal work on olfaction - the sensory system concerned with smell. Smell is crucial to animals: they use it to recognize other animals, identify territories and seek out mates, for example. Humans rely on it rather less, but still benefit from being able to smell burning from a distance, for instance, or tell if meat has gone bad.

Twenty years ago, olfaction was the Cinderella of sensory physiology. Back then, neuroscientists were more enamoured of the visual system - and were making great progress towards cracking its mysteries. By 1986, the three main colour receptors - for red, blue and green light — had all been discovered, and scientists had a clear idea of the combinatory code that allows us to perceive light of different wavelengths and identify all the colours of the rainbow.

The small community of olfactory scientists were still working in the dark, however. It was understood that the cells in the lining of the nose bind the molecules that comprise odours, then send electrical signals to the olfactory bulb in the brain, and that from there the information must be relayed to higher parts of the brain concerned with smell recognition. But researchers were confined to sticking electrodes into brains without even knowing what receptors the odour molecules bind to.

\section{Persistent effort}

Buck and Axel changed all that. As a postdoc at Axel's Howard Hughes Medical Institute (HHMI) laboratory at Columbia University, Buck became fixated with the problem of the mysterious olfactory receptors. Picking up on recent hints in the scientific literature that smell receptors could be related to the small family of vision receptors, she adapted a freshly developed tool, the polymerase chain reaction (PCR), to serve her ends. PCR amplifies specific genes to detectable levels, and Buck used it in an effort to flush out her receptors in rats. This approach was novel at the time, but has since become routine. After initially failing, she modified the approach — and failed again. And again. Then, after six years, she succeeded.

Together with Axel, she published a paper that shook the world of sensory physiology

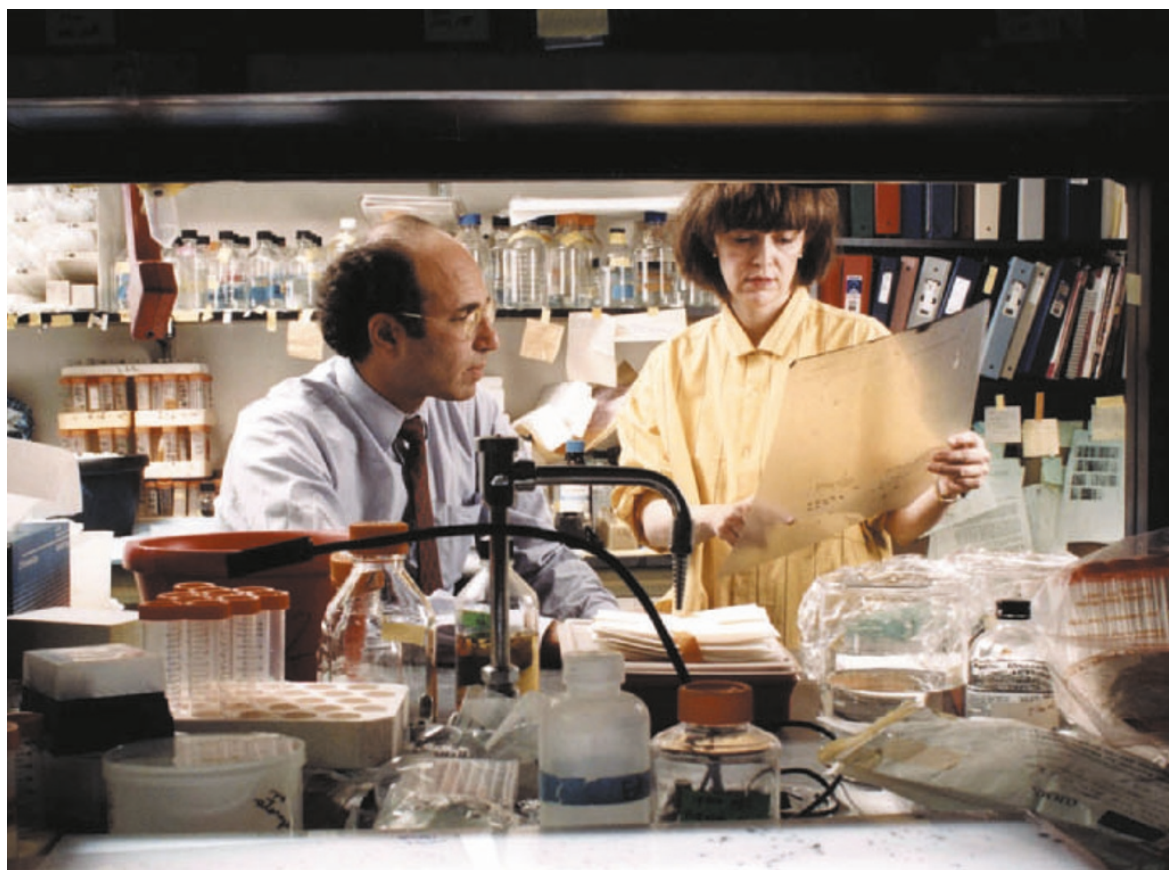

Perfect sense: Richard Axel and Linda Buck discovered the receptors that bind odour molecules.

(see Cell 65, 175-187; 1991). The receptors were indeed part of the same family as visual receptors - a family that signals through a class of protein known as $G$ proteins. But the olfactory sub-family wasn't the anticipated tight-knit group: it had about a thousand members. Similarly unexpected was the finding that each cell in the lining of the nose contains only one type of olfactory receptor. Each of these cells sends projections to the olfactory bulb. The two researchers went on to show independently that all cells bearing a particular receptor converge on a precise region in the olfactory bulb.

The next big advance will be to understand exactly what happens next - how the signal becomes the perception of a smell with all its associations - the danger of fire, for example, or the hope of love in a perfume. Scientists believe that olfaction will serve as a model for understanding how our brain processes all the sensory information gleaned from our world.

Both Axel and Buck are still working on the higher processing of olfactory signals, but the field is much more crowded now. Their seminal 1991 paper drew researchers into the field in droves. Among them was Lawrence Katz, a self-confessed "hard-core vision scientist" at Duke University Medical Center in Durham, North Carolina. Katz says that Buck and Axel's work "had a tremendous influence on how I thought about how sensory systems could be organized in the brain".

Like many of his colleagues, Katz soon became convinced that the olfactory system was much more likely to help illumi- nate the general problem of sensory perception than was vision. "The perception of the olfactory signal — smell — is probably going to be much more closely linked to the molecular signal itself, in contrast to visual perception, whose complexities require much more processing of the signal input," he says.

Colleagues ascribe Axel and Buck's success in unearthing the roots of olfaction to their personal doggedness, underpinned by the steady, powerful support that the HHMI gives its researchers. "It would have been hard to do this if you were required to produce regular publications to support your next grant," points out Stuart Firestein, a neuroscientist at Columbia University in New York, who also works on olfaction. The HHMI has nurtured 13 Nobel prizewinners since it was established in 1984.

Firestein says that the award is also a shot in the arm for basic research, because there is, as yet, no direct medical application for Axel and Buck's findings. He notes, nonetheless, that half of all drugs work through G-protein receptors of different types. So having another thousand to investigate as a result of their approach "is certain to help medicine indirectly", he says.

Buck becomes only the seventh woman to win the Nobel prize for physiology or medicine: fewer than one in 25 laureates in this category have been women.

For more news and analysis go to news@nature.com www.nature.com/news 